\title{
(Un)Conditional Welfare? Tensions Between Welfare Rights and Migration Control in Swiss Case Law
}

\author{
Lisa Marie Borrelli*, Stefanie Kurt* ${ }^{*}$ Christin Achermann** , and Luca Pfirter *
}

\begin{abstract}
This analysis of Swiss Federal Supreme Court judgements shows the coupling of welfare and migration control. Foreign nationals depending on social assistance might face the withdrawal of their residence permits. We show how the conveyed legal logics create conditionality of rights and a differentiation of (non-) citizens. The judgements individualise social assistance dependence and follow a neoliberal logic of economic participation. They establish rationalities which reinforce politics of belonging and welfare chauvinism.
\end{abstract}

Keywords: Social assistance, migration control, welfare chauvinism, exclusion, case law

\section{(Un)bedingte Wohlfahrt? Spannungen zwischen Wohlfahrtsrechten und Migrations- kontrolle in der Schweizer Rechtsprechung}

Zusammenfassung: Eine Analyse der Rechtsprechung des Schweizer Bundesgerichts zeigt die Kopplung von Sozialleistungsbezug und Migrationskontrolle. Ausländer*innen, die von Sozialhilfe abhängig sind, können ihren Aufenthaltsstatus verlieren. Die Urteile zeigen rechtliche Logiken, welche Rechte an Bedingungen knüpfen und zwischen (Nicht-)Bürger*innen differenzieren. Sie basieren auf der Individualisierung von Sozialhilfeabhängigkeit und einer neoliberalen Logik der wirtschaftlichen Teilhabe. Dies verstärkt eine Politik der Zugehörigkeit und Wohlfahrtschauvinismus.

Schlüsselwörter: Sozialhilfe, Migrationskontrolle, welfare chauvinism, Exklusion, Rechtsprechung

\section{Une aide sociale (non) conditionnelle? Tensions entre droits sociaux et contrôle des migrations dans la jurisprudence suisse}

Résumé: L’analyse des arrêts du Tribunal fédéral suisse montre le lien entre les prestations sociales et le contrôle des migrations. Les étrangers qui dépendent de l'aide sociale peuvent perdre leur permis de séjour. La logique juridique véhiculée crée la conditionnalité des droits et la différenciation des (non)citoyens. Les jugements individualisent la dépendance à l'aide sociale et suivent une logique néolibérale de participation économique. Ils établissent des rationalités qui renforcent la politique d'appartenance et soutiennent le chauvinisme social. Mots-clés: Aide sociale, contrôle des migrations, welfare chauvinism, exclusion, jurisprudence

\footnotetext{
* HES-SO Valais-Wallis, CH-3960 Sierre, lisa.borrelli@hevs.ch, stefanie.kurt@hevs.ch

** University of Neuchâtel, CH-2000 Neuchâtel, christin.achermann@unine.ch, luca.pfirter@ unine.ch
} 


\section{Introduction ${ }^{1}$}

The dependency is - as the previous instance has rightly determined - to a broad extent self-inflicted. The claimant was warned lby the migration office] on June $4^{\text {th }}, 2013$, to free herself from social assistance; after this did not happen, she was warned by the migration office on November $18^{\text {th }}, 2014$, again, without success. [...] it cannot be assumed that a detachment from social assistance will happen within reasonable time, because the claimant did not participate in any work in the primary labour market since 2011. (2C_870/2018, own translation)

The role of law, and in the above case the role of legal judgments (see also Johannesson $2012 ; 2018$ ), has been thoroughly studied through multiple lenses within sociolegal studies (Bourdieu 1987; Collier and Starr 1989; Eckert et al. 2012; Calavita 2016). This literature highlights the relevance of everyday negotiations, but also to what extent legal regulations and law itself contribute to social control, enabling and constraining power (Cotterrell 1992). Consequently, court judgements, such as the extract above, allow for a careful study of how these rulings contribute to the embedding of legal logics and interpretations in society and how they convey and create normative ideas. The presented extract is one example of how foreign nationals' right to stay is perceived and questioned by public authorities, leading to a withdrawal or a non-prolongation of (permanent) residence permits in Switzerland. A long and significant dependence on social welfare, here deemed self-inflicted, goes against the public interest and is often interpreted as a sign of lacking integration, leading to the loss of residence permit and therefore eventually to deportation (cf. Bolzman et al. 2002). Such cases reveal how welfare and migration control are heavily intertwined and how tensions between both play out in bureaucratic and legal decision-making. Although one set of policies might grant support (social assistance), the reception can at the same time be circumscribed by others (restrictive migration policies) and follow an enforcement logic (Bourdieu 2012; Spencer 2016).

Our interest lies in tracing this tension between welfare rights and migration control, for which we propose a case study of Swiss case law (see Pellander 2021). We ask the following question: What does case law of the Swiss Federal Supreme Court (FSC) tell us about the relationship between the reception of social assistance and non-citizens' legitimacy/right to stay in Switzerland? The focus on case law exceeds previous research, which preferred to study policies (Ataç 2019) and neglected the relevance of legal decision-making within state institutions, in particular courts. Yet, prior socio-legal work brought forward how courts are constructed as bounded space[s] of specialist dialogues which create an "ordered progression toward the

$1 \quad$ Acknowledgements: The article was supported by the National Centre of Competence in Research nccr - on the move, which is funded by the Swiss National Science Foundation (51NF40-182897). 
truth" (Bourdieu 1987, 830). Our interest lies in what judgments by the hierarchically highest court can teach us about the establishment of truths, rationalities, symbolic effects and the coupling of welfare benefits and migration control. Such an analysis presents an original way to reveal how states mobilise motivations and arguments in terms of (non-)access to social assistance and how they legitimise their exclusionary practices.

Under certain circumstances (see Art. 83 of the Federal Law on the FSC), individuals whose permits are revoked or not prolonged can appeal the decision as far up as the FSC in order to secure their stay in Switzerland (Spescha et al. 2019). Hence, the FSC represents the last instance of a chain of legitimisation by controlling decisions of lower instances in their exercise of discretion and enforcement of law (Art. 96 FNIA). As such, judgments by the FSC legitimise enforcements and decisions by other actors within the chain of legitimisation, down to the streetlevel bureaucrat. By removing prior logics of enforcement from the "category of arbitrary violence" (Bourdieu 1987, 824), these judgments legitimately (re)produce power structures within society, manifesting perceptions of normalcy and deviancy (Bourdieu 1987, 847).

The argumentation within the introductory judgement reflects the conditionality of rights and as such the differentiation between deserving citizens and non-citizens, who are seen as an illegitimate burden to the public hand of the Swiss state. Additionally, we claim that the presented court judgements individualise social assistance dependency (see also Procacci 2001) and follow a strong neoliberal logic of economic participation. We support this with concepts of "welfare chauvinism" (see Andersen and Bjørklund 1990; Huysmans 2006), "domopolitics" (Walters 2004) and "politics of belonging" (Yuval-Davis 2011) or rather "non-belonging".

After a brief description of the Swiss legal system and the case selection, we will first elaborate these theoretical concepts and then apply them to our data. The analytical section presents how (past) individual behaviour is contrasted against the public interest, but also how the future is constructed to the disadvantage of claimants. Further, court rulings ascribe significant responsibility to those receiving benefits, not only through constructing social assistance dependency as being selfinflicted, but also through an assumed "unteachability" (Pfirter 2019) of foreign nationals, which is considered to show their "lack of integration". 


\section{The Revocation or Non-Prolongation of a (Permanent) Residence Permit in the Case of Social Assistance Dependency - The Legal Perspective}

The issuance of residence permits (B permits) and permanent residence permits (C permits) ${ }^{2}$ is regulated by the FNIA (Federal Act on Foreign Nationals and Integration, formerly Foreign Nationals Act, FNA). A permanent residence permit can be issued after a minimum rightful stay of five or ten years and is based on meeting further (integration) criteria in Switzerland (see also Kurt 2017 on settlement treaties). ${ }^{3}$ Additionally, there is a legal difference between so-called "third-country nationals" and "citizens of the European Union/EFTA" (Spescha 2011). Although integration criteria as well as the nationality of the foreign national might hinder access to more "stable" permits, those factors also influence the revocation, and respectively the non-prolongation, of permits (for further information, see Spescha 2011). ${ }^{4}$

Besides convictions for criminal sentences, or violations towards public security, to name just a few reasons, withdrawal of a residence permit is possible if a person or someone s/he takes care of (e.g. spouse) depends on social assistance (Art. 62 FNIA). For the withdrawal of a permanent residence permit, these reasons need to be fulfilled on a more extensive level, including a permanent dependence on social assistance to a substantial extent (Art. 63 FNIA). Further, whereas permanent residency holders were protected by their length of stay (if residing for more than 15 years) when depending on social assistance under the FNA (change of Art. 63. Para. 2 FNA; Kurt 2017), the change to the FNIA nullified this safety.

The withdrawal, decided by cantonal and municipal migration offices, revokes the person's legal status and allows for his or her removal (Spescha 2011; Spescha et al. 2019). Based on the jurisprudence of the FSC, the withdrawal of a permit due to social assistance dependency is practised in the case of a concrete danger of (long-term) social dependency (e.g. high financial contributions and no or little indication that the concerned person will become financially independent). Additionally, the withdrawal of a permanent residence permit is possible after receiving around 80,000 Swiss francs of social assistance within two to three years. Financial contributions of labour market integration programmes by the state are also interpreted as social assistance (Bundesrat 2019, 18). Yet, specific circumstances, such as

2 Due to the focus of this research, issued residence permits based on the Asylum Act will not be discussed, because the permits of recognised refugees and temporarily admitted foreign nationals cannot be revoked for social assistance dependency. Yet, dependency affects those groups in other ways (Amarelle and Nguyen 2014; Caroni et al. 2018; Spescha et al. 2015; 2019).

3 An exception are foreign professors nominated at one of the universities or higher education institutes and their family members, who receive a permanent residence permit immediately upon their first entry and stay in Switzerland.

4 To simplify the legal complexity, we will only use the term "withdrawal of (permanent) residence permit" in the following part, despite various legal differentiations between expiry, withdrawal and non-prolongation. 
the family situation or childcare duties, need to be considered. Probst et al. (2019) further underline that despite the possibility to withdraw purely due to dependence on social assistance, many cantons highlight the need to consider the overall case and its individuality to avoid an "automatisation" of the withdrawal procedure.

Whereas decisions by cantonal migration offices can be appealed within the internal cantonal instances (depending on the structure of each canton) and lastly to the cantonal courts, only some cases are taken up by the FSC (depending on the claimant's entitlement regulated by law; see Spescha et al. 2019). This also explains the rather small number of cases dealing with this issue. If the FSC rejects the appeal, the concerned person may appeal before the European Court of Human Rights (ECHR).

\section{Methodological Case Law Selection and Analysis}

Our inquiry of the FSC's case law resulted in 18 cases, ${ }^{5}$ of which 17 were rejected and received a non-admission decision and one was admitted by the FSC. One case treats the withdrawal of a permanent residence permit, whereas the other 17 cases discuss the withdrawal of a residence permit. All cases deal with foreign nationals from third countries. The 18 cases were thematically coded according to their reasons for withdrawal and aspects of the specific case (e. g. legal background, children, social assistance, integration, private interest of stay), which are analysed and described below. During the coding process four supplementary cases (all rejected) were added to our database, which did not come up in our previous search, but were referenced in the other FSC judgements. Three cases are particularly interesting as they deal with long term residing foreign nationals (since 1985, 1990 and 1998) and one case with an amount of social assistance over 600000 Swiss Francs. Thus, we had a total of 22 cases ( 18 from the search, and 4 from references cited in jurisprudence).

Hence, the seemingly small number of cases appears in a different light, if we consider that they represent the overall standing of legal understandings regarding welfare and immigration control in Switzerland. They contribute to the creation of normalcy and deviancy (see also Soysüren 2018), universalising specific modes of living, and set how lower legal and administrative actors will handle future cases (Bourdieu 1987). Within the history of welfare law, Bourdieu (1987) argues that

5 In a first step, we identified case law of the Swiss Federal Supreme Court focusing on Art. 62 para. 1 lit. e FNA (today FNIA) and Art. 63 para. 1 lit. c FNA (today FNIA), respectively, thus two different retrievals. We used the FSC's website and searched for cases between the period of

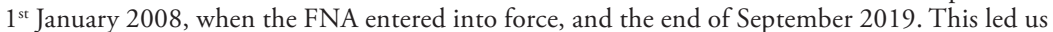
to 1124 hits in the case of Art. 62 para. 1 lit. e FNA and 703 hits in the case of Art. 63 para. 1 lit. c FNA. Subsequently, we added the words "revocation" or "non-prolongation" coupled with "public welfare" in both cases. It resulted in 17/15 exact cases, which fully met the research criteria for Art. 62 para. 1 lit. e FNA and in 10/7 exact cases for Art. 63 para. 1 lit. c FNA. Subsequently, we took out duplicate cases, leaving us with 18 cases in total. All of them were analysed in depth. 
"the body of law constantly registers a state of power relations. It thus legitimises victories over the dominated, which are thereby converted into accepted facts" (Bourdieu 1987, 817).

Importantly, law neither simply obeys external social forces that ask for mere implementation (of, e.g., restrictive migration policies), nor is law detached from society and its power relations. Instead, law and its related institutions are a specific field with its own logics and power struggles, while in constant interaction with society at large (Bourdieu 1987). The analysed judgements are part of this juridical field and include sections where new interpretations manifest, as well as sections that are constructed of standardised text modules, which "offer a 'yardstick' for how to argue regarding certain assertions" (Poertner 2021, 77). The standardisation shows how certain aspects of law and legal interpretation have gained stability and where a common understanding (of case aspects) is carved out and confirms the established order (Bourdieu 1987, 839).

\section{Theoretical Background}

Switzerland, as much as other countries, distinguishes between various migrant categories by regulating a differentiated access to rights, not only connected to their entry, but also regarding their stay and based on an assumed "degree of integration" (Morris 2002; Pascouau and Strik 2012; Goodman 2019). Similarly, states classify their poor population into subcategories to establish who deserves financial support from the state (Maeder and Nadai 2004; Tabin et al. 2008; Wacquant 2009; Leerkes 2016). We thus argue that "poor" foreign nationals are a specific state category, especially affected not only by the recent slimming down of welfare state expenditures, but also by tightening migration control practices (Bolzman et al. 2002; Walters 2004; Leerkes 2016; Ataç and Rosenberger 2019). The right to have (social) rights (Arendt 1949) thus becomes a "civic privilege" (Bolzman et al. 2002; Tafelmacher 2010; Chauvin and Garcés-Mascareñas 2014; Suvarierol and Kirk 2015), linked to ideas of deservingness and conditionality (van Oorschot 2006). Consequentially, individuals face differentiated allocation of welfare rights based on "civic stratification", a system of inequality (Morris 2002) that (legally) in- or excludes (Achermann 2013), grants or denies rights established by eligibility criteria. The stratification also allows for the "elaboration of rights for categories of noncitizens" (Morris 2002, 79) that is coupled with the exercise of control and surveillance (Piñeiro 2015). Here, only citizens are fully recognised as legitimate members of the national solidary group that is entitled to welfare (Bolzman et al. 2002; Maeder and Nadai 2004; Mäder 2009). This stratification is not new, because access to welfare has evolved - being expanded and restricted - regarding various groups over time (Maeder and Nadai 2004; Tabin 2002; Tabin et al. 2008). 
Historical analysis highlighted how poverty was seen as evidence of idleness (Procacci 2007; Wacquant 2009), making "the poor" a "political and not a charity problem" (Procacci 2007, 27) and linking (active) citizenship to the notion of "useful" and hard work (Marshall 1950; Procacci 2001). Over the past decades, scholars have been increasingly interested in the question of how non-citizens became another target group who face "welfare state chauvinism" (Andersen and Bjørklund 1990; later "welfare chauvinism", see Huysmans 2006), which conceptualises the differentiation between citizens and non-citizens regarding welfare policies. This work argues for the emerging notion of a "welfare state [that] should [...] be protected against abuse by people who don't want to work, or against the burden imposed by immigrants, refugees, and similar outgroups" (Andersen and Bjørklund 1990, 204). Similarly, Huysmans argues that states purposefully and explicitly privilege nationals "in contrast to third-country nationals" $(2006,64)$, with the effect of creating a widespread suspicion towards asylum seekers and migrants in general. Additionally, Ataç and Rosenberger (2019) argue that there is a convergence of social policies and migration policy, in particular affecting irregular migrants (see also Leerkes 2016).

We broaden this discussion by showing that besides social policies differentiating access to welfare, migration policy also restricts the right to access welfare services, not only for irregularised individuals, but also for "legally residing" foreign nationals in Switzerland (cf. Bolzman et al. 2002; Pfirter 2019). The Swiss state increasingly links welfare benefits with migration control, partly due to the fear of alleged "foreign welfare abusers" (Tabin 2002). Thereby, welfare benefits and post-entry migration control become increasingly intertwined (Ataç and Rosenberger 2019). This is in line with Walters' argument (2004) that feelings of insecurity revolving around the geographical and territorial borders have shifted towards a social insecurity, due to which states try to increase trust of their citizens through tougher policies against those deemed not belonging and/or undeserving. Foreign nationals become mere "guests" in a "home" which is not theirs, tolerated as long as they have no criminal record (Achermann 2008; 2013), participate (economically and socially) and do not make any claims towards the "host society", such as asking for financial support in times of need (Walters 2004).

States thus establish "domopolitics" (Walters 2004), referring to the government of the state and further political spaces as a home and of belonging, which needs to be protected. As observed already nearly 20 years ago in the Swiss case, the reception of social assistance jeopardises the right to stay and to family reunification (Bolzman et al. 2002). Historically, also Swiss belonging as such was contested and highly connected to the "hometown" (inherited by one's father). It determined, for example, which community was responsible for "the poor" individual and which community needed to pay (back) social assistance expenditures (received by an individual) to another community (the hometown or the place of residence; Tabin et al. 2008). 
This article shifts the focus from policy analysis towards case law and decisionmaking by bureaucratic administration which is endorsed, as we show, by the FSC. These "judgment[s] represent[...] the quintessential form of authorized, public and official speech which is spoken in the name of and to everyone" (Bourdieu 1987,838 ) by simultaneously refusing and delegitimising other points of view. Through the hierarchical organisation of the juridical field, these judgments are translated back into bureaucratic decision-making (Bourdieu 1987). The article thus contributes to studies of publicly available rulings/judgements and verdicts on the national level (Pellander 2021), which are yet often neglected. Much like the work of Pellander, who studied Finnish state "control mechanisms over cross-border marriages" (Pellander 2021, 475), our findings bring forward how money - and in our context the dependence on financial assistance - plays a crucial role in the general discourse on migrants' deservingness and the legitimacy of their stay on the national territory. Studying the argumentation of court rulings informs us on how the Swiss welfare state is thought of: namely as a privilege mainly for citizens of the nationally bound community of solidarity. (Economic) integration is a necessary requirement to belong and functions as a means to sort the "wanted" from the "unwanted" (Walters 2004; Fassin 2011; Achermann 2013). These court cases are then not only influenced by recent policy developments, such as the discussion on abuse of social welfare (Tafelmacher 2010), but also (re)direct control practices and everyday implementation in bureaucratic offices.

\section{$5 \quad(U n)$ conditional Welfare in Switzerland}

The presented, systematic review of FSC judgments elaborates themes which emerged during the analysis. Much like Sales (2002), we argue that welfare rights become increasingly linked to duties one has to fulfil. A lack of "integration" is mobilised to discredit individual efforts and clearly places a focus on "public interest, order and security" (see Art. 121 and 121a Swiss Constitution) against which the personal interest of the accused is weighed. All cases, except one, show how the FSC argues in favour of terminating the stay of non-citizens due to the reception of social assistance. The court justifies such a decision against the arguments of the concerned individuals and families. It considers the claimants' previous behaviour, their future prospects (here, state institutions are expected to foresee the potential development of not only the person in question, but the financial situation of the entire family), the amount of financial assistance and the personal "integration" (e. g. length of stay or whether they fulfil the legal integration requirements). Reasons for dependency and thus blame (or responsibility) become relevant matters regarding the risk to lose a permit (Pfirter 2019), as does the question of proportionality. Regarding the latter, the public interest is weighed against the private interest of the individual, 
including how the person is "integrated" into Swiss society (see Achermann 2013 for the handling of criminal offenders).

\subsection{Cost Avoidance, Temporal Prospects and Suspicion}

The cases show quite clearly that the FSC considers non-citizens who receive social assistance as not legitimate and thus undeserving to continue their stay in Switzerland. They are a burden to the nation-state's financial situation:

[It is] out of question, that the claimant has received $173403.55 \mathrm{CHF}$ between January $1^{\text {st }}, 2007$, and July 31 $1^{\text {st }}, 2015$, in social assistance. At the moment one cannot expect that he will be able to take care of his subsistence on his own in the near future, especially since his neediness has endured over the past 10 years and he believes himself to be $100 \%$ incapacitated. (2C_1048/2017, own translation)

Unlike deservingness frameworks in which neediness could become an advantage for asylum seekers (van Oorschot 2000; 2006; Ataç 2019), placing a (future) economic burden on the welfare state and eventually remaining needy have serious consequences for individuals whose stay is judged under the former FNA. Previous developments of each case have to be weighed and considered in the context of the claimant's current living situation, as well as with a forecast of the foreseeable development of his or her financial and personal situation. Here, time plays a crucial role to establish claimants as unable to contribute economically, to live independently and to integrate, which justifies withdrawal of their stay permits. The number of years of "neediness" is also used to establish the "unwillingness" of the client, underlining the individualisation of the reasons for receiving social assistance (cf. Pfirter 2019). Here, responsibility is transferred entirely onto the claimants, who could easily change their situation if they only wanted to do so. The FSC further questions the claimant's perceived inability to work due to health reasons (2C_98/2018), underlining how the "neediness" is self-constructed, not accepted by the administration and thus illegitimate. His or her poor prospects are perceived as a sign of idleness and an attempt to circumvent "hard work" (Procacci 2001; 2007).

Within the cases, the necessity of bringing forward evidence of financial independence as well as justifications of the current financial situation and developments weighs heavily on the claimants. This supports an inherent suspicion and the questioning of their deservingness to receive social assistance, a recurrent theme throughout all judgements. Indeed, credibility is primarily given to the arguments of administrative actors who prove their standpoints through paperwork (Borrelli and Andreetta 2019; Borrelli and Lindberg 2019) rather than to the claimant's own perception of the situation (2C_1048/2017). This need for evidence is further connected to an assessment of future (or rather temporal) prospects, which become crucial indicators and a valid measure to decide on the termination of someone's 
permit "in order to relieve public welfare" (2C_1040/2017, own translation; see also reference to 2C_1064/2017). The focus to relieve the public hand creates the image of undeserved support that legitimises the termination of stay of a foreign national. It underlines the differentiation of rights (see Morris 2002; Andersen and Bjørklund 1990), based on migration policies interfering with or rather trumping social policies.

In one judgement, the lack to "integrate into the primary labour market in a foreseeable timeframe" (2C_1040/2017, own translation) is brought up. Yet, if individuals found a job during the revocation process, the court interprets it as an endeavour, which came "too late" and only after migration offices pressured the individual (2C_98/2018). We also find a mobilisation of other welfare benefits in order to prove the likely future burden for the Swiss state, specifically used against persons who are eligible for supplementary benefits. ${ }^{6}$ Although these supplementary benefits are in themselves not a legal reason to withdraw a residence permit, they "may be taken into consideration, when assessing the proportionality of measures regarding the termination of stay" (2C_98/2018, own translation):

In case the claimant would receive her AHV [Old-Age Survivors Insurance] pension at an earlier stage, this would cause a life-long shortage of her pension; her future subsistence would need to be covered substantially by supplementary benefits. This would in practice mean a seamless continuation of her existing dependence on social assistance. Through this anticipated life-long dependence on needs-based minimum benefits in form of special services, which are independent of prior contributions, the public hand would continue to be considerably burdened. (2C_98/2018, own translation; see also 2C_83/2018)

The weight placed on the "public hand" is underlined several more times in the same judgement and overshadows the rights of the claimant, who is deemed unable to "take care of herself by her own efforts", because she will soon be retired and receiving an AHV pension. Again, although each retired person is entitled to receive AHV, it is interpreted as a burden in the context of migration law, which causes a conflation of differing welfare state instruments. A husband "at the end of professional life" and his wife, who were denied invalidity benefits, received $440000 \mathrm{CHF}$ in social assistance. Both lost their permits, despite the husband's part-time employment of $50 \%$ right after the migration office's decision was taken, which made the couple immediately independent of social assistance (2C_83/2018). However, the court argued that the wife had not worked since a prior accident and that neither spouse participated in secondary labour market programmes, so they were responsible for their prior dependency. The court argued that neither would receive an existence-

6 According to the Federal Act on Supplementary Benefits to Old Age, Survivors' and Disability Insurance (own translation, ELG, 6. October 2006, 01.01.2019) 
securing pension. It further speculated ("in all likelihood") that they would require supplementary benefits in the future. Hence, the verdict was based on a prognosis that "neither would be able to detach themselves durably from social assistance and the general support of the public hand" (2C_83/2018, own translation). In addition to the potential disadvantage of old age, young claimants also face temporal hurdles. The FSC explained that "today one cannot assume that [a younger claimant's] ability to take care of his livelihood will change in the future" (2C_877/2013, own translation).

With the mobilisation of an image of foreign nationals burdening the state in the long run, these rulings place claimants in direct competition with citizens for public money. Even if children support their parents and alleviate their financial dependence temporarily, the court places importance on future developments and their individual efforts and "capacities" for independence from public funds. In the case of an older couple, the FSC not only expected them to have some evidence of the children's financial situation, but also stated that although they received support from their children, this would not change their individual "incapacities" for independence from welfare benefits. Hence, to provide a positive future prognosis, they had to prove their employability, respectively, and prove that they would earn a generally livelihood-securing wage in the future (2C_949/2017). Although the claimants argued that they would eventually receive invalidity pensions (IV) despite previous rejections in 2009/2010 and 2015, the FSC assessed that this reasoning remained "purely speculative regarding the general entitlement to such a pension, as well as its amount" (2C_949/2017, own translation).

Ironically, the element of speculation is also highly embedded in future predictions conducted by state agencies. Yet, these are treated as far more valid and reliable. One explanation lies in the migration offices' belonging to the juridical field, as these offices implement laws partially shaped by the FSC. Their enforcement authority derives from the legitimacy of the law itself and juridical arguments (re)produced and justified in FSC judgements. These judgements become a form of public truth proclamation representing the state's general position and thus claiming to speak "in the name of and to everyone" (Bourdieu 1987, 838). The FSC chooses which interpretations are deemed valid and thus produces normalcy in terms of which predictions (or speculations) are legitimate. This reproduces established societal hierarchies and differentiations, specifically through the individualisation of social assistance dependency.

\subsection{The Individualisation of Economic and Social Integration}

The wife's insufficient interest in learning German is related to her inability to "integrate" into the primary labour market. The husband is further judged according to his "massive unreliability, repeated refusal to work" and scant 
employment, which only took place in the context of integration programs and only up to $80 \%$ "because the claimant denied the possibility of working full-time to keep Friday free for prayers". (2C_1064/2017, own summary)

As much as the temporal aspects "prove" claimants' unwillingness, their behaviour and alleged lack of integration also contribute to evidence of the claimants' undeserving nature. Within the analysed court rulings, images of individual failures to comply with expected levels of integration emerge. These failures might be indirectly attributed to religious differences (e.g. praying on Fridays) or a general disobedience to public control. Our analysis also emphasises images of (un)deservingness in which the assessment of the person's interest in staying is strongly based on ideas of economic deservingness (Ticktin 2006; Chauvin and Garcés-Mascareñas 2014).

The claimant may now have lived in Switzerland for more than 25 years, but regarding his specific circumstances, it must be concluded that the length of his residence does not correlate with his economic and social integration. [...] Despite his health problems, it would have been reasonable for him to put effort into finding adequate employment, especially since his ability to work was legally determined to be $70 \%$, and $80 \%$ by the IV. Therefore, he is - contrary to his argument - at fault regarding his social assistance dependency. Furthermore, the claimant has accumulated debts that amount to $75000 \mathrm{CHF}$, the latest ones from 2015, and he is further reproached for "not having specifically tight social relations in Switzerland, despite his lengthy stay". (2C_1048/2017, own translation)

The presented case contrasts the claimant with the FSC's "ideal image," against which foreign nationals' lives are assessed and judged, and consequently establishes that he does not deserve the right to stay. Migrant individuals are held responsible and culpable for their dependence on social assistance, making them scapegoats which, due to the financial burden they represent, threaten the stability of the Swiss welfare system.

Most cases emphasise economic independence (no debts, no social assistance and working in the primary labour market) when assessing a person's integration and right to stay. Integration is reduced to a one-sided performance, measurable in terms of monetary possession rather than other factors. Although language skills (see cases 2C_419/2018 and 2C_870/2018) and relationships may be considered factors related to integration, financial independence is the most significant factor on which integration seems to be based:

The claimant has lived in Switzerland for nearly 29 years. Regarding her specific circumstances, particularly her continuous dependence on social assistance and its amount, it must be concluded that her length of stay does 
not correlate with her economic and social integration. (2C_953/2018, own translation)

As this example demonstrates, rulings utilise standardised templates, which come up repeatedly. The repetitive nature of some sections reinforces the power of certain arguments. At the same time, the rulings include a certain storyline which lists progressively severe negative developments. In one case, the FSC mentioned, how despite "massive social assistance", the claimant was given "a last chance" with the previous extension of his residence permit (2C_1109/2014, own translation). However, he did not act upon this "chance", and thus the public had a "significant" interest in his leaving, especially because he was relatively young, and the FSC assumed that he would remain dependent "for a long time".

Social assistance dependency is indirectly described as self-induced in the case reports (see 2C_1109/2014 or 2C_1040/2017), which allows the FSC to restrict "the right to have rights" (Arendt 1949) and legitimise their withdrawal. Individuals who justify their dependence on social assistance with their state of health are depicted as not sick enough, malingering patients who pretend to be unable to work (2C_1048/2017 2018), or idle (2C_870/2018). The statements of these non-citizens are constantly contested, and the judgements legitimise this contestation by referring to the court's role of reducing the public burden. They "position themselves as a force for good, acting in many cases to protect [...] their citizens" (Walters 2004, 248) against those who misuse the welfare system. This can be explained in terms of welfare chauvinism: The courts oppose the financial burden caused by foreign nationals and thus reproduce a picture of the illegimate nature of receiving such benefits, which is supported by the general political discourse directed against foreign nationals and translated into respective legal changes (Spescha et al. 2019).

Family life and childrearing are not relevant to decisions regarding the termination of the stay in cases of lengthy social assistance dependency, which outweighs the stay itself: " 17 years of idleness, in which [the claimant] did not contribute to the financial support of the family, despite being warned twice and being offered several integration courses by the social services" (2C_395/2017, own translation). While the court considers children's needs and their eventual issues, these are only marginally valid for the final decision. Interestingly, even previous employment may be used as an argument of the FSC to disadvantage the claimants' position. Because one claimant (2C_870/2018) was employed part-time until 2011, it was said that her dependence on social assistance resulted from her "lacking motivation in the following years to seriously seek an existence-securing employment, especially since her son was already in kindergarten/school" (2C_870/2018, own translation). Here, a lack of motivation is connected to the assumption that one has 'the time' to work since children are taken care of. In addition, even if one looks for work, lacking knowledge of the local language becomes a reason for terminating the stay because a lack of serious will to integrate is presumed (2C_870/2018). 
These judgements illustrate how administrations create expectations and norms that are subsequently confirmed and supported in the court's verdicts. Once a person is deemed undeserving based on previous behaviour, present efforts are not easily recognised. In Bourdieu's $(1987,847)$ conceptualisation of the juridical field, court decisions set representations of normalcy and deviation from the norm. This normalising effect of court judgements confirms social assistance as a privilege "reserved" for citizens, which additionally enjoy an inalienable right to stay (Marshall 1950). Foreign nationals are, in turn, required to fulfil increasingly complex integration requirements (Pascouau and Strik 2012; Ataç 2014; Goodman 2019). These are often linked to an individualised and neoliberal logic of economic contribution, responsibility and performance (Yuval-Davis et al. 2005). Court cases thus become tools for social ordering, through which borders (of belonging) become manifest in the everyday lives of foreign nationals who have often resided (and worked) in Switzerland for many years. The judgements reproduce the non-belonging of noncitizens, who were never recognised as fully part of society to begin with (Yuval-Davis et al. 2018). Instead, their already differentiated status is further questioned when they claim that they are unable to work.

As such, not only policies, but also court cases and judgements create hierarchies of deservingness against which claimants are judged and based on which their behaviour is discouraged and categorised as disruptive (Ataç 2019). By arguing against the claimants and describing their reasons for the dependence on social assistance based on individualised (moral) defects, including idleness or want (Beveridge 1942; Walters 2004), states can position themselves as being responsible, protecting their citizens from persons allegedly misusing the system (Walters 2004, 248).

\subsection{Individual Rights versus "Public" Interest}

Although there is no entitlement for third-country nationals to enter or stay in a foreign state's territory (contrary to the human right to exit), the FSC must consider claimants' private interests to assess the proportionality of state decisions. The termination of their stay may jeopardise Art. 8 of the ECHR (the right to respect for private and family life), which might be considered by the court. ${ }^{7}$ The FSC argues that, in the case of a residence of 10 years, exceptional reasons are needed to terminate one's stay "because after this timespan a good integration regularly exists" (2C_291/2019, own translation). Neither the "feasibility of return as reason per se" nor the "public interest to manage immigration" is sufficient for a termination. However, if there are reasons such as a perceived prolonged and self-inflicted dependence on social assistance, intrusion into private life becomes admissible and is practised. In one example case, the FSC deemed that the person had "absolutely no

7 In the case of the termination of stay of criminal offenders, reasons related to Art. 8 ECHR are the only ones which might lead authorities or courts to consider a revocation or non-prolongation of a permit as being disproportional (Achermann 2013). 
valid" claim to private life (2C_291/2019, own translation). Such withdrawals are based on Art. 8, para. 2 of the ECHR if deemed necessary and are "in the interest of national security, public safety or the economic well-being of the country, for the prevention of disorder or crime, for the protection of health or morals, or for the protection of the rights and freedoms of others" (ECHR, Art. 8 para. 2). The termination of the stay can only be prevented, according to the FSC, if the claimant has an "outstanding social need", but neither what this entails nor what is considered unacceptable is mentioned explicitly (2C_291/2019; 2C_98/2018; 2C_395/2017 2018). Instead all the presented needs within the cases do not seem to be sufficient.

In these judgements, we find an overall logic of domopolitics (Walters 2004), which is aimed at governing political spaces in a manner similar to domestic spaces. When weighing private lives and the public interest, the FSC deems, for example, the separation of families to be justified and proportional (2C_395/2017). Although the FSC places the responsibility of deciding whether children (and eventually the spouse) must follow on the claimant whose residence permit is withdrawn (2C_395/2017), it also discloses an exclusionary logic. If one spouse leaves, eventually the rest of the family might follow, further reducing potential future costs to the Swiss state. This demonstrates that the respective individuals' stay has always been conditional. Similarly, if the court recognises an enduring need of the state's supporting a foreign national, it tends to attribute responsibility for this support to the state of which the person is a citizen. This applies even if the court acknowledges unfavourable conditions in the country of origin (2C_1109/2014). In this reasoning, we find a parallel between the treatment of migrants today as well as how, in the past, "the poor" were sent back to their respective "home communities", which were considered responsible for their members (Tabin 2002). Today's laws serve the purpose of sending those considered to be a burden "back home", leading to their deportation back to their "hometowns" or, in today's context, their "home countries". The meaning of "hometown" as such has not lost its meaning, but has been transferred to the national level, and the law no longer differentiates between local community memberships, but between national memberships.

\subsection{Unteachability, Duties and Responsibility}

In its judgements, the FSC insists on non-citizens' duty to actually find work and does not acknowledge their efforts to do so. Thereby, the court not only qualifies people's attempts to re-integrate economically, but also closes off avenues for claimants to advocate for their rights to stay and receive benefits. In one case mentioned above, "the lengthy dependence on social assistance indicates a lack of flawless behaviour" (2C_870/2018, own translation). It is further argued that "a single mother can be expected to seek employment after the youngest child turns three and that she does not rely on social assistance to finance her life" (2C_730/2018, own translation; see also 2C_633/2018; 2C_395/2017). However, despite participation in work 
integration programs through which the claimant acquired a partial income, the amount was considered insufficient (2C_730/2018). Further, we again find that the courts attempt to discipline behaviour. Even the act of fulfilling a duty as a social assistance recipient to participate in integration programs (2C_395/2017; 2C_83/2018) can be turned against the claimant. This occurs when participation in these programs is on the one hand presented as a sign of continued dependence on social assistance rather than a sign of detaching from state support. On the other hand, participation in these programs is interpreted not as a demonstration of a personal effort to change one's situation, but merely as the consequence of following rules whose disrespect would involve the reduction of social assistance. The court reduces the person's effort and the positive connotations of participation to the fulfilment of a "duty" stemming from social law (2C_870/2018), which obliges them to partake in these programs and which, if ignored, can lead to a reduction in financial assistance as part of the sanctioning system within social policies. Furthermore, it openly admits that this duty "qualifies the relevance of her [...] effort" (2C_870/2018 2019, own translation). With this judgment, the FSC supports the tightening of migration control practices through social policies (Huysmans 2006; Leerkes 2016). The qualification of individual efforts increases the requirements for migrant individuals to remain in the country.

Moreover, even difficult family circumstances do not spare claimants from being accused of idleness. A woman who came to Switzerland when she was 19 years old and whose husband lost his employment four years later (one year after the birth of their child) lost her permit (2C_395/2017). This happened despite her husband "losing hold, consuming drugs and suffering from alcohol abuse" (own translation). According to the court, the woman should have sought employment instead of remaining dependent on her husband and hoping he would regain the ability to work.

The focus on duty remains closely connected to the idea that individuals must contribute and make an effort. Indeed, the collected judgements hint at the assumption that some people are "unteachable" and thus undeserving of support (Pfirter 2019). In the case of a Bosnian woman, her "unteachability" became the key argument for terminating her stay. Despite the fact that her morbid (healthimpaired) husband and 12-year-old son (who was in school) both possessed permanent residence permits, the court ruled that "despite warnings, she did not make any effort to reduce her social assistance dependency and integrate economically or linguistically" (2C_419/2018, own translation). Although the court discussed the potential problems related to re-integrating into her home country, as well as the son's inability to visit his mother over long periods if he and his father stayed in Switzerland, the claimant's "minimal effort to integrate" and her "massive, selfinflicted social assistance dependency" ranked higher than her right to live with her family in Switzerland (2C_419/2018, own translation). 
Arguing with unteachability allows the court to place full responsibility on the claimant, who has been warned and informed but has "wilfully decided" not to act (Pfirter 2019; 2C_83/2018). Here, the temporal aspects used to envision idleness (e. g. the length of welfare dependency) work well together with a presumed lack of motivation to create the 'faulty and non-deserving other'. One claimant's employability was rated at $50 \%$ a few months after an accident, and it was determined that "he did not try hard enough" (2C_83/2018 2019). "He ought to have taken up a job", the court claimed. Even though local social services attested that the claimant tried and "met his obligations and basic duty to minimise damages", the court ruled that the permit withdrawal was proportional, even if the claimant fulfilled his obligation, because "foreigner-related procedures follow a sterner benchmark" (2C_395/2018, own translation). Here, the court openly acknowledged a hierarchy of policies (i.e. migration policy trumps social policy). In addition, it confirmed that foreign nationals' claims to social rights are conditional. In this sense, their claim to social assistance comes at a high price that leads to suspicion, monitoring, sanctioning and eventually deportation.

\section{Conclusion}

Within this work, we elaborate on the question of what FSC case law reveals about the relationship between the receipt of social assistance and non-citizens' legitimacy and right to remain in Switzerland. We have argued that the Swiss state mobilises the receipt of social welfare as a means to establish conceptions of normalcy and deviancy and to question belonging (Walters 2004) through administrative and legal decision-making. This argument was supported by an analysis of FSC case law concerning judgements on foreign nationals and their legal right to remain in the country when depending on social assistance. Throughout the four analytical sections, we demonstrated how welfare rights function as tools of civic stratification, and we showed how citizens are differentiated from non-citizens. While noncitizens can nowadays access the universal social rights that used to be a privilege of the national solidary group (Marshall 1950), they experience significantly higher conditions than citizens and risk deportation.

First, we showed how aspects of temporality established the failure to become independent of social assistance and how "late reactions" might have increased suspicion on the FSC's part towards the claimant's willingness to integrate. Second, we found an individualisation of dependency. In addition to the exclusion of "the poor", we also tackled "migrants with poor prospects" (Bonjour and Duyvendak 2018). Although there was a change in the $20^{\text {th }}$ century regarding which social and economic processes were seen as the underlying causes of poverty (Walters 2004) we have today circled back to an image of individuals, especially migrants, as responsible 
for their dependency. Third, we showed that the presented court decisions, particularly previous decisions by migration offices, cantonal courts and legal representatives, reflect a general binary of "protectionism" towards the welfare state and the citizens who "belong" to it, as contrasted with those groups perceived as non-integrated, undeserving and therefore facing deportation. Fourth, we showed how terms such as "integration", "self-infliction" and "unteachability" became crucial indicators for assuming the failure of foreign nationals to live up to their duties. This supports Huysmans' (2006) argument that the policing of borders and access to social and economic rights are embedded in polarised debates on belonging.

Welfare and immigration policies are strongly intertwined; thus, migrants become the rivals of citizens, with whom they compete for social benefits. As such, welfare chauvinism becomes "a strategy of introducing cultural identity criteria in an area in which belonging is determined on the basis of social policy criteria, such as health, age, disability and employment" (Huysmans 2006, 78). The court's wording reflects the expectation of an idealised behaviour of migrant individuals, by which each claimant is judged. The foremost markers of belonging include labour market participation and economic independence, as well as "flawless" behaviour and not showing idleness or insufficient motivation. Doubt surrounding "being integrated" and remaining or becoming independent of social assistance is enshrined in law "as a quintessential instrument of normalisation" (Bourdieu 1987, 848), which curtails the rights of immigrants and causes serious repercussions, such as deportation from Switzerland.

By relating the receipt of social assistance to a potential loss of residence status, current migration control practices call into question the existence of social assistance that is available to everyone regardless of status and origin (Tabin 2002). Furthermore, these practices redefine and demonstrate who belongs and whose presence becomes politicised (Houtum and Naerssen 2002; Brubaker 2010; Cassidy et al. 2017), establishing a "politics of belonging that is not generated by migration, at least not in any proximate sense, but by various forms of social closure, discrimination, or marginalization" (Brubaker 2010, 65). The sense of belonging is deeply embedded, as presented here, in the stratification of social rights, and more specifically in the conditions related to the receipt of social assistance.

Interesting for future comparison and analysis is the convergence we identified between how foreign national offenders are treated vis-à-vis foreign nationals who rely on social assistance. Achermann (2013) highlighted the spatial and social exclusion of foreign national offenders and the permanently insecure status, which also affects other migrant groups and disciplines their behaviour. Similar to those sentenced to prison and therefore marked as general security threats to public order and the nation, those relying on social assistance must demonstrate their worthiness to stay, which is assessed based on their performance and their valid and strong rela- 
tion to (and thus integration into) Swiss society, all of which affect the judgement regarding their future right to stay.

\section{$7 \quad$ References}

Achermann, Christin. 2008. Straffällig, Unerwünscht, Ausgeschlossen: Ausländische Strafgefangene in der Schweiz. Doctoral dissertation, Social Anthropology, University of Bern.

Achermann, Christin. 2013. Excluding the Unwanted: Dealing with Foreign-National Offenders in Switzerland. Pp. 91-109 in Politik der Inklusion und Exklusion, edited by Ilker Ataç and Sieglinde Rosenberger. Göttingen: V\&R unipress.

Amarelle, Cesla, and Minh Son Nguyen (eds). 2014. Code annoté de droit des migrations. Vol. I-V. Berne: Stämpfli Verlag AG.

Andersen, Jørgen Goul, and Tor Bjørklund. 1990. Structural Change and New Cleavages: The Progress Parties in Denmark and Norway. Acta Sociologica 33(3): 195-217.

Arendt, Hannah. 1949. The Rights of Man: What Are They? Modern Review 3: 4-37.

Ataç, Ilker. 2014. Conditions as Internal Borders: The Case of 'Security of Residence' for Third-Country Nationals in Austria. Pp. 123-136 in New Border and Citizenship Politics, edited by Helen Schwenken and Sabine Ruß-Sattar. Migration, Diasporas and Citizenship Series. London: Palgrave Macmillan UK.

Ataç, Ilker. 2019. Deserving Shelter: Conditional Access to Accommodation for Rejected Asylum Seekers in Austria, the Netherlands, and Sweden. Journal of Immigrant \& Refugee Studies 17(1): 44-60.

Ataç, Ilker, and Sieglinde Rosenberger. 2019. Social Policies as a Tool of Migration Control. Journal of Immigrant \& Refugee Studies 17(1): 1-10.

Beveridge, William. 1942. Social Insurance and Allied Services. London: Inter-Departmental Committee on Social Insurance and Allied Services, HMSO.

Bolzman, Claudio, Raffaella Poncioni-Derigo, Sophie Rodari, and Jean-Pierre Tabin. 2002. La précarité contagieuse: les conséquences de l'aide sociale sur le statut de séjour des personnes de nationalité étrangère. L'exemple des cantons de Genève et Vaud. Lausanne; Genève: Ed. EESP; Ed. IES.

Bonjour, Saskia, and Jan Willem Duyvendak. 2018. The "Migrant with Poor Prospects": Racialized Intersections of Class and Culture in Dutch Civic Integration Debates. Ethnic and Racial Studies 41(5): 882-900.

Borrelli, Lisa Marie, and Sophie Andreetta. 2019. Introduction. Journal of Legal Anthropology 3(2): 1-9.

Borrelli, Lisa Marie, and Annika Lindberg. 2019. Paperwork Performances. Journal of Legal Anthropology 3(2): 50-69.

Bourdieu, Pierre. 1987. The Force of Law: Toward a Sociology of the Juridical Field. The Hastings Law Journal 38(5): 814-853.

Bourdieu, Pierre. 2012. Sur l'État: cours au Collège de France, 1989-1992. Cours et Travaux. Paris: Seuil.

Brubaker, Rogers. 2010. Migration, Membership, and the Modern Nation-State: Internal and External Dimensions of the Politics of Belonging. The Journal of Interdisciplinary History 41(1): 61-78.

Bundesrat. 2019. Kompetenzen des Bundes im Bereich der Sozialhilfe für Ausländerinnen und Ausländer aus Drittstaaten. Bericht des Bundesrates in Erfüllung des Postulates der Staatspolitischen Kommission des Ständerates 17.3260 vom 30. März 2017. Bern. https://www.sem.admin.ch/dam/data/sem/ aktuell/news/2019/2019-06-07/ber-br-d.pdf. (18.06.2020).

Calavita, Kitty. 2016. Invitation to Law \& Society: An Introduction to the Study of Real Law. $2^{\text {nd }}$ ed. The Chicago Series in Law and Society. Chicago; London: The University of Chicago Press. 
Caroni, Martina, Nicole Scheiber, Christa Preisig, and Margarite Zoeteweij (eds.). 2018. Migrationsrecht. 4. Auflage. Bern: Stämpfli Verlag.

Cassidy, Kathryn, Nira Yuval-Davis, and Georgie Wemyss. 2017. Debordering and Everyday (Re)Bordering in and of Dover: Post-Borderland Borderscapes. Political Geography 66: 171-179.

Chauvin, Sébastien, and Blanca Garcés-Mascareñas. 2014. Becoming Less Illegal: Deservingness Frames and Undocumented Migrant Incorporation. Sociology Compass 8(4): 422-432.

Collier, Jane F., and June Starr (eds). 1989. History and Power in the Study of Law: New Directions in Legal Anthropology. Ithaca and London: Cornell University Press.

Cotterrell, Roger. 1992. The Sociology of Law: An Introduction. $2^{\text {nd }}$ ed. London: Butterworths.

Eckert, Julia, Brian Donahoe, Christian Strümpell, and Zerrin Özlem Biner (eds). 2012. Law Against the State: Ethnographic Forays into Law's Transformations. Cambridge: Cambridge University Press.

Fassin, Didier. 2011. Policing Borders, Producing Boundaries: The Governmentality of Immigration in Dark Times. Annual Review of Anthropology 40(1): 213-226.

Federal Act on Foreign Nationals and Integration. 2019. https://www.admin.ch/opc/en/classified-compilation/20020232/index.html. (18.06.2020).

Goodman, Sara Wallace. 2019. The Civic Integration Turn. Pp. 167-179 in The Routledge Handbook of the Politics of Migration in Europe, edited by Agnieszka Weinar, Saskia Bonjour, and Lyubov Zhyznomirska. London; New York: Routledge.

Houtum, Henk van, and Ton van Naerssen. 2002. Bordering, Ordering, and Othering. Tijdschrift voor Economische en Sociale Geografie, 93(2): 125-136.

Huysmans, Jef. 2006. The Politics of Insecurity: Fear, Migration and Asylum in the EU. London: Routledge.

Johannesson, Livia. 2012. Performing Credibility: Assessments of Asylum Claims in Swedish Migration Courts. Retferd Årgang 35 3(138): 69-84.

Johannesson, Livia. 2018. Exploring the "Liberal Paradox" from the Inside: Evidence from the Swedish Migration Courts. International Migration Review 52(4): 1162-1185.

Kurt, Stefanie. 2017. Fast-Tracking Full Citizenship in the Context of the Swiss Integration Stage Model. Working Paper nccr on the move. https://nccr-onthemove.ch/wp_live14/wp-content/ uploads/2017/11/nccrotm-WP15-Kurt.pdf. (18.06.2020).

Leerkes, Arjen. 2016. Back to the Poorhouse? Social Protection and Social Control of Unauthorised Immigrants in the Shadow of the Welfare State. Journal of European Social Policy 26(2): 140-154.

Mäder, Ueli. 2009. Integration oder Ausschluss- die neue soziale Frage? Implikationen für die soziale Sicherung. Pp 143-162 in Sozialhilfe in der Schweiz: Klassifikation, Integration und Ausschluss von Klienten, edited by Stefan Kutzner, Ueli Mäder, Carlo Knöpfel, Claudia Heinzmann, and Daniel Pakoci. Nationales Forschungsprogramm NFP 51, Integration und Ausschluss. Zürich: Rüegger.

Maeder, Christoph, and Eva Nadai. 2004. Organisierte Armut: Sozialhilfe aus wissenssoziologischer Sicht. Konstanz: UVK-Verl.-Ges.

Marshall, Thomas H. 1950. Citizenship and Social Class. Cambridge: Cambridge University Press.

Morris, Lydia. 2002. Managing Migration: Civic Stratification and Migrants' Rights. London; New York: Routledge.

Oorschot, Wim van. 2000. Who Should Get What, and Why? On Deservingness Criteria and the Conditionality of Solidarity among the Public. Policy and Politics: Studies of Local Government and Its Services 28(1): 33-48.

Oorschot, Wim van. 2006. Making the Difference in Social Europe: Deservingness Perceptions among Citizens of European Welfare States. Journal of European Social Policy 16(1): 23-42.

Pascouau, Yves, and Tineke Strik. 2012. Which Integration Policies for Migrants? Interaction between the EU and Its Member States. Nijmegen: Wolf. 
Pellander, Saara. 2021. Buy Me Love: Entanglements of Citizenship, Income and Emotions in Regulating Marriage Migration. Journal of Ethnic and Migration Studies 47(2): 464-479.

Pfirter, Luca. 2019. Constructing "Unteachability" Through Menacing Warnings. Journal of Legal Anthropology 3(2): 29-49.

Pińeiro, Esteban. 2015. Integration und Abwehr: Genealogie der schweizerischen Ausländerintegration. Zürich: Seismo.

Poertner, Ephraim. 2021. Re-Cording Lives: Governing Asylum in Switzerland and the Need to Resolve. Bielefeld: transcript.

Probst, Johanna, Gianni D’Amato, Samantha Dunning, Denise Efionayi-Mäder, Joëlle Fehlmann, Andreas Perret, Didier Ruedin, and Irina Sille. 2019. Kantonale Spielräume im Wandel: Migrationspolitik in der Schweiz. Neuchâtel: SFM/nccr - on the move.

Procacci, Giovanna. 2001. Poor Citizens. Social Citizenship versus Individualization of Welfare. Pp. 49-68 in Citizenship, Markets, and the State, edited by Colin Crouch, Klau Eder, and Damian Tambini. Oxford: Oxford University Press.

Procacci, Giovanna. 2007. Genealogies of Poverty: From Inclusion Towards Exclusion. Development 50(2): 26-30.

Sales, Rosemary. 2002. The Deserving and the Undeserving? Refugees, Asylum Seekers and Welfare in Britain. Critical Social Policy 22(3): 456-478.

Soysüren, Ibrahim. 2018. L'expulsion des étrangers en France, en Suisse et en Turquie: pour une sociologie comparative de l'expulsion des étrangers. Neuchâtel: Alphil éditions.

Spencer, Sarah. 2016. Postcode Lottery for Europe's Undocumented Children: Unravelling an Uneven Geography of Entitlements in the European Union. American Behavioral Scientist 60(13): 1613-1628.

Spescha, Marc. 2011. Bewilligungen können erlöschen, widerrufen oder nicht verlängert werden. Terra Cognita 18: 70-74.

Spescha, Marc, Hanspeter Thür, Andreas Zünd, Peter Bolzli, and Constantin Hruschka (eds.). 2015. Migrationsrecht: Kommentar: Schweizerisches Ausländergesetz (AuG), Asylgesetz (AsylG) und Freizügigkeitsabkommen (FZA) mit weiteren Erlassen. 4., aktualisierte und erweiterte Auflage. Zürich: Orell Füssli Verlag.

Spescha, Marc, Andreas Zünd, Peter Bolzli, Constantin Hruschka, Fanny de Weck, and Valerio Priuli. 2019. Migrationsrecht: Kommentar: Schweizerisches Ausländer- und Integrationsgesetz (AIG), Asylgesetz (AsylG) und Freizügigkeitsabkommen (FZA) sowie Bürgerrechtsgesetz (BüG) mit weiteren Erlassen. Zürich: Orell Füssli Verlag.

Suvarierol, Semin, and Katherine Kirk. 2015. Dutch Civic Integration Courses as Neoliberal Citizenship Rituals. Citizenship Studies 19(3-4): 248-266.

Tabin, Jean-Pierre. 2002. L'importance de la question des destinataires de l'assistance publique pour la construction de l'identité nationale : l'exemple de la Suisse. Chronos 3(64): 88-109.

Tabin, Jean-Pierre, Arnaud Frauenfelder, Carola Togni, and Véréna Keller. 2008. Temps d'assistance: le gouvernement des pauvres en Suisse romande depuis la fin du XIX'e siècle. Lausanne: Ed. Antipodes.

Tafelmacher, Christophe. 2010. Polémique sur l'expulsion des "criminels étrangers» et projet de transformation radicale de l'État. Chimères 74(3): 77-84.

Ticktin, Miriam. 2006. Where Ethics and Politics Meet. American Ethnologist 33(1): 33-49.

Wacquant, Loï J. D. 2009. Punishing the Poor: The Neoliberal Government of Social Insecurity. Durham [NC]: Duke University Press.

Walters, William. 2004. Secure Borders, Safe Haven, Domopolitics. Citizenship Studies 8(3): 237-260.

Yuval-Davis, Nira. 2011. Belonging and the Politics of Belonging. Pp. 20-35 in Contesting Recognition, edited by Janice McLaughlin, Peter Phillimore, and Diane Richardson. London: Palgrave Macmillan UK. 
Yuval-Davis, Nira, Floya Anthias, and Eleonore Kofman. 2005. Secure Borders and Safe Haven and the Gendered Politics of Belonging: Beyond Social Cohesion. Ethnic and Racial Studies 28(3): 513-535.

Yuval-Davis, Nira, Georgie Wemyss, and Kathryn Cassidy. 2018. Everyday Bordering, Belonging and the Reorientation of British Immigration Legislation. Sociology 52(2): 228-244.

\title{
8 Decisions by the Swiss Federal Court FSC
}

\author{
2C_877/2013, 03.07.2014 \\ 2C_1109/2014, 20.07.2015 \\ 2C_395/2017, 07.06.2018 \\ 2C_949/2017, 23.03.2018 \\ 2C_1040/2017, 21.12.2018 \\ 2C_1048/2017, 13.08.2018 \\ 2C_1064/2017, 15.06.2018 \\ 2C_83/2018, 01.02.2019 \\ 2C_98/2018, 07.11.2018 \\ 2C_419/2018, 29.10.2018 \\ 2C_633/2018, 13.02.2019 \\ 2C_730/2018, 20.03.2019 \\ 2C_870/2018, 13.05.2019 \\ 2C_953/2018, 23.01.2019 \\ 2C_291/2019, 09.08.2019
}

